\title{
Papillary, Follicular, Hurthle Cell, Poorly Differentiated, and Anaplastic Thyroid Carcinoma cN0 TNM Finding v8
}

National Cancer Institute

\section{Source}

National Cancer Institute. Papillary, Follicular, Hurthle Cell, Poorly Differentiated, and Anaplastic Thyroid Carcinoma cNO TNM Finding v8. NCI Thesaurus. Code C140904.

No evidence of locoregional lymph node metastasis. (from AJCC 8th Ed.) 